\title{
Monoclonal antibodies developed for detection of an epizootic virus associated with mass mortalities of cultured scallop Chlamys farreri
}

\author{
Chongluo $\mathrm{Fu}^{1,2}$, Weibo Song ${ }^{1, *}$, Yun $\mathrm{Li}^{1}$ \\ ${ }^{1}$ The Key Laboratory of Mariculture, Ministry of Education, Ocean University of China, Qingdao 266003, PR China \\ ${ }^{2}$ College of Life Science, Liaocheng University, Liaocheng 252059, PR China
}

\begin{abstract}
Recently, an enveloped, spherical RNA virus was identified as the causative agent of mass mortalities among adult scallop Chlamys farreri, which is cultured on the northern coast of China. Hybridomas were prepared from mice immunized with highly purified virions. Four stable hybridomas secreting monoclonal antibodies (MAbs) of IgG isotype were obtained after screening by means of enzyme-linked immunosorbent assay (ELISA) and immunofluorescence assay (IFA). The specificity of the MAbs to this virus was confirmed by immunogold electron microscopy (IEM). All the selected MAbs recognized epitopes on the envelope spikes of the virions. Subsequently, the MAbs were used for in situ immunofluorescent detection of the virus in Davidson's fixed tissue sections. The results showed that the fluorescent cells were mostly observed in epithelia of different organs, but not in the epithelium of the digestive diverticulae. Cytopathological changes and focal lesions corresponding to virus-positive cells were clearly recognized in the affected epithelia, revealing a potential role of this virus in pathogenesis.
\end{abstract}

KEY WORDS: Scallop $\cdot$ Chlamys farreri $\cdot$ Acute virus necrobiotic disease $\cdot$ Monoclonal antibodies

\section{INTRODUCTION}

The scallop Chlamys farreri is widely farmed along the northern coast of China. In the 1980s, an abnormal occurrence of mass mortality among cultured and wild adults was initially reported in some regions of Shandong Province (Liu et al. 1992). Since the mid-1990s, the scallop farming industry in China has experienced a period of severe crisis due to ongoing outbreaks of mass mortality. Mortality occurred annually during late summer and could approach $90 \%$ within 5 to $8 \mathrm{~d}$ after the event began (Yu et al. 1998, Guo et al. 1999).

In a search for the causative agent, a number of tentative hypotheses have been proposed (Wang \& Xiang 1999, Zhang \& Yang 1999, Li et al. 2002, Xiao et al. 2003). More recently, supported by the 'Key Project of Chinese National Programs for Fundamental Research and Development (973 program)', systematic investigations including epidemiological surveys (X. H. Wang et al. 2002, He et al. 2003), RNA studies on the causative agent (Huang et al. 2002) and experimental infections (Ai et al. 2003) have been carried out by our research group since 2000. All results suggested that the causative agent is an unknown spherical virus. Based on the results obtained, the disease was named 'acute virus necrobiotic disease (AVND)' (Song et al. 2001).

Currently, the tissue distribution of the AVND virus and its role in pathogenesis are still obscure. Hence, the main goal of the present study was to develop reliable monoclonal antibodies (MAbs) against the AVND virus to allow sensitive detection of virus antigens and a simultaneous evaluation of histopathological changes in diseased scallops.

\section{MATERIALS AND METHODS}

Virus collection and purification. Moribund scallops Chlamys farreri (14 to 15 mo old) were collected during 
mass mortalities in mid-July 2001 and 2002 from several private farms in Qingdao and Rizhao (Shandong Province of China). The gills and mantles were removed from the scallops and stored at $-85^{\circ} \mathrm{C}$ before use. Virus purification by centrifugation was performed according to C. M. Wang et al. (2002). Tissues were homogenized in 8 volumes of TEN buffer $(50 \mathrm{mM}$ Tris- $\mathrm{HCl}_{i} 10 \mathrm{mM}$ EDTA; $360 \mathrm{mM} \mathrm{NaCl}, \mathrm{pH} 7.8$ ) and clarified by 2 low speed centrifugations $(3500 \times g$ for $15 \mathrm{~min}$ followed by $7500 \times g$ for $15 \mathrm{~min})$. All centrifugations were carried out at $4^{\circ} \mathrm{C}$. The supernatants were then concentrated by sedimentation through a $6 \mathrm{ml}$ cushion of $35 \%$ sucrose $(\mathrm{w} / \mathrm{w})$ at $113000 \times \mathrm{g}$ for $90 \mathrm{~min}$ and the resulting pellets were resuspended in TEN buffer. After centrifugation at $8000 \times g$ for $20 \mathrm{~min}$, supernatants were layered onto a 30 to $60 \%(\mathrm{w} / \mathrm{w})$ continuous sucrose density gradient. After centrifugation at $113000 \times g$ for $2.5 \mathrm{~h}$, the opalescent virus containing band was collected. The virus was washed with TN buffer ( $50 \mathrm{mM}$ Tris- $\left.\mathrm{HCl}_{;} 360 \mathrm{mM} \mathrm{NaCl}, \mathrm{pH} 7.8\right)$ and resuspended in a small amount of TN buffer. The purity was checked by a transmission electron microscope (TEM, JEOL JEM-1200) using $2 \%$ phosphotungustic acid (PTA, pH 7.0) as the negative stain. The concentration of viral proteins was determined using the procedure described by Bradford (1976).

Hybridoma production. Eight week old BALB/C mice were immunized intraperitoneally (i.p.) with purified virus $\left(100 \mu \mathrm{g} \mathrm{mouse}^{-1}\right)$ mixed with an equal volume of Freund's complete adjuvant (Gibco). Subsequent boosters with antigen in incomplete adjuvant were given on Days 14, 28, and 42. Three days before cell fusion, mice received the last immunization via intrasplenic injection $\left(20 \mu \mathrm{g} \mathrm{mouse}^{-1}\right)$ with the purified virus diluted in phosphate buffered saline (PBS), but without adjuvant. Antibody titers to AVND virus in the mice were checked by means of enzyme-linked immunosorbent assay (ELISA) as described below.

Spleen cells from the immunized mice were fused with NS-1 myeloma cells at a ratio of 5:1 using polyethylene glycol (PEG 2000, $50 \%$ ). The fused cells were resuspended with RPMI-HAT (Gibco) medium and plated into 96-well microplates in the presence of normal mouse spleen cells serving as feeder cells. After about 1 wk of cultivation, HAT medium was partially replaced by HT (Gibco) medium and hybridoma supernatants were screened for antibody production from Day 10 onwards by ELISA. Positive hybridomas were subsequently cloned 3 times by limiting dilution. The immunoglobulin (Ig) isotype of the MAbs was determined using a Mouse Monoclonal Antibody Isotyping Kit (Sigma) according to the manufacturer's instructions.

Hybridoma supernatants with high antibody titers were collected and applied directly. Antibodies were also produced by injecting hybridomas into the peritoneal cavity of $10 \mathrm{wk}$ old BALB/c mice. After hybridoma cell proliferation, ascitic fluids with high antibody titers were obtained within 2 to $4 \mathrm{wk}$.

ELISA. An ELISA method was standardized to screen the hybridoma supernatants. Briefly, the purified virus was solubilized with $1 \%$ SDS and diluted in carbonate-buffer (pH 9.6) (Lucht et al. 2003). Then, the virus antigen was coated to the solid phase of 96-well high binding EIA/RIA plates (Costa) overnight at $4^{\circ} \mathrm{C}$. After removing the antigen fluid, nonspecific binding sites were blocked with $3 \%$ bovine serum albumin (BSA)-PBS, followed by incubation for $30 \mathrm{~min}$ at $37^{\circ} \mathrm{C}$. The wells were emptied and hybridoma supernatants were added and incubated for $1 \mathrm{~h}$ at $37^{\circ} \mathrm{C}$. After washing the plates 3 times for 5 min by immersion in PBST (0.05\% Tween-20 in PBS), HRP-conjugated goat antimouse IgG (H\&L) (Sino-American Biotechnology; diluted 1:1000) was added and incubated for $1 \mathrm{~h}$ at $37^{\circ} \mathrm{C}$. After washing as above, substrate solution $(0.1$ $\mathrm{M}$ citrate/phosphate buffer, pH 5.0; $0.04 \%$ OPD, Sigma; $0.15 \% \mathrm{H}_{2} \mathrm{O}_{2}$ ) was applied for $15 \mathrm{~min}$ at room temperature. The reaction was stopped by $2 \mathrm{M} \mathrm{H}_{2} \mathrm{SO}_{4}$ and the optical density (OD) of each well was read at $492 \mathrm{~nm}$ using a plate reader (Labsystems Mutiskan MK3).

Positive controls (P) corresponded to immunized mouse sera (diluted 1:16 000), obtained $3 \mathrm{~d}$ before cell fusion. Homogenate (diluted 1:1000) of healthy scallop tissues (mantle and gill) served as negative controls (N). These healthy scallops were sampled in spring 2003 and were examined by TEM to confirm viral-free status. Supernatants of $\mathrm{OD}_{492 \mathrm{~nm}} \mathrm{P} / \mathrm{N} \leq 2.1$ were selected for further cloning and subsequent testing by immunofluorescence assay (IFA).

IFA on fixed sections. Diseased (moribund) scallops were collected from a private farm during mass mortality in 2003. Healthy scallops serving as negative controls were the same as above. Mantles, gills, and parts of kidney, gonad, hepatopancreas, stomach and intestine were dissected, fixed with cold Davidson's alcohol-formalin-acetic solution for 24 to $48 \mathrm{~h}$, and stored in $70 \%$ ethanol solution before use. The specimens were processed using a routine laboratory procedure (Lighter 1996). For immunofluorescence staining, sections were deparaffinized in xylene and rehydrated in graded ethanols, followed by washing 3 times with PBST. The sections were incubated with hybridoma supernatants in a moist chamber for $1 \mathrm{~h}$ at $37^{\circ} \mathrm{C}$. After washing 3 times with PBST, the sections were incubated with FITC-conjugated goat anti-mouse IgG (H\&L) (diluted 1:10) in a dark moist chamber for $1 \mathrm{~h}$ at $37^{\circ} \mathrm{C}$. After extensive washing, the slides were mounted in $50 \%$ glycerol and examined with a fluorescence microscope (Olympus B $\times 50$ ). 
Immunogold electron microscopy (IEM). Formvarcoated grids were placed on to 25 to $30 \mu \mathrm{l}$ purified virus aliquots for $1 \mathrm{~min}$. All subsequent steps were performed by floating the grids with the specimen side down on aliquots of the solutions, in a moist chamber with parafilm at its base at room temperature (Gowen et al. 2003). After washing 3 times with PBS, nonspecific binding was controlled by incubation with $3 \%$ BSA-PBS for $30 \mathrm{~min}$. The grids were then exposed for $1 \mathrm{~h}$ to the hybridoma supernatants. The grids were washed 3 times with PBS and then transferred to drops of $10 \mathrm{~nm}$ colloidal gold-conjugated goat anti-mouse IgG (whole molecule) (Sigma, G7777; diluted 1:10 in $3 \%$ BSA-PBS) for $1 \mathrm{~h}$. After all labeling steps, the grids were washed 3 times for 5 min each time with PBS and 3 times for 1 min with distilled water. Finally, the virus was stained with $2 \%$ PTA and viewed by TEM.

\section{RESULTS}

\section{Virus purification}

Virions purified by sucrose gradient centrifugation are shown in Fig. 1. The virions were spherical, and possessed a bilaminal envelope with dense spikes on its surface. They were about 130 to $170 \mathrm{~nm}$ in diameter, while the nucleocapsids were 90 to $140 \mathrm{~nm}$.

\section{Production and screening of hybridomas}

The fused cells were cultured in 4 96-well plates. After cultivation in HAT medium for $2 \mathrm{wk}$, hybridomas survived in 249 wells and the fusion rate was about $65 \%$. In the initial screening by ELISA, 12 wells containing hybridomas were capable of secreting anti-

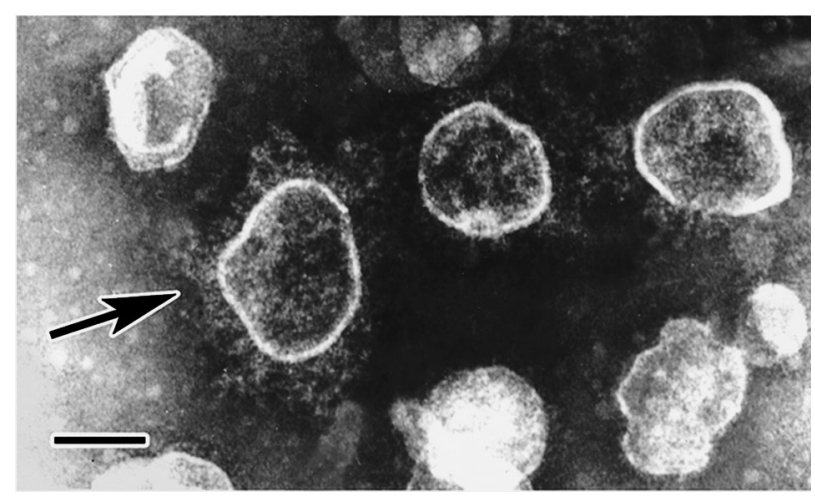

Fig. 1. Negatively stained acute virus necrobiotic disease (AVND) virions purified from moribund Chlamys farreri by density gradient centrifugation. Intact virions with dense spikes on their envelope were clearly observed (arrow). Scale bar $=100 \mathrm{~nm}$ bodies that reacted with purified virus preparation. After subcloning 3 times to ensure monoclonality, indirect IFA was carried out to confirm their specificity to AVND virus. Ten of the 12 MAbs reacted with mantle and other tissues of diseased (moribund) scallops but not with any tissues of healthy scallops (negative controls). The other 2 MAbs reacted with hemocytes of diseased and healthy scallops (data not shown). Of the 10 MAbs that reacted with diseased tissues in IFA, 4 MAbs (2B3, 3C8, 3G7 and 4C7) were eventually chosen for further study because of their strong reactivity and high stability in culture (Table 1).

\section{IEM}

For confirmation purposes, the 4 selected MAbs were examined by immune electron microscopy and $10 \mathrm{~nm}$ colloidal gold was used as a marker to visually detect their combining positions on AVND virions. For all MAbs (2B3, 3C8, 3G7 and 4C7), specific labeling was observed on the envelope of AVND virions, indicating that the epitopes recognized by these 4 MAbs were on the envelope of the virus (Fig. 2).

Table 1. Characterization of selected monoclonal antibodies (MAbs). Immunoglobulin (Ig) class or subclass; reaction with acute virus necrobiotic disease (AVND) virus in ELISA and immunofluorescence assay (IFA). +: weak reaction; ++ : strong reaction $;+++$ : very strong reaction

\begin{tabular}{|llcc|}
\hline \multirow{2}{*}{ MAbs } & \multirow{2}{*}{ Subclass } & \multicolumn{2}{c|}{ Intensity of reaction in } \\
& & ELISA & IFA \\
\hline 2B3 & IgG2b & +++ & ++ \\
3C8 & IgG1 & +++ & +++ \\
3G7 & IgG2b & ++ & + \\
4 C7 & IgG2b & ++ & + \\
& & & ++ \\
\hline
\end{tabular}

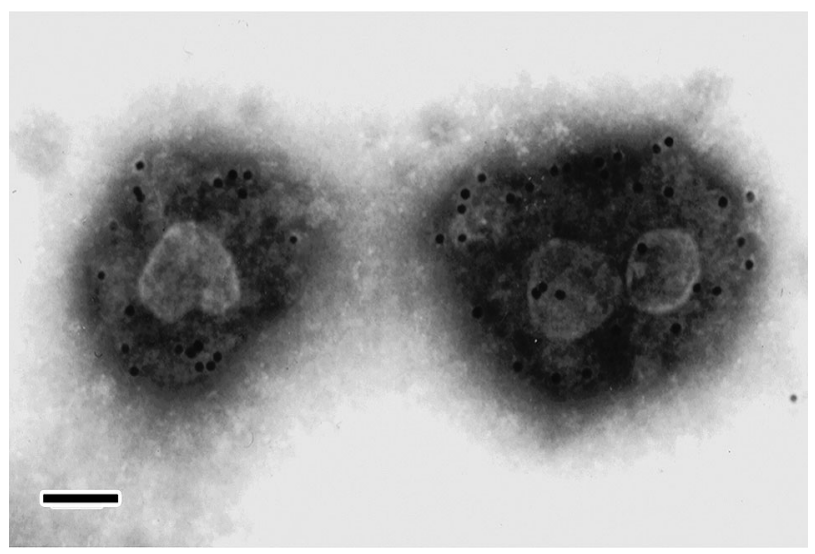

Fig. 2. Monoclonal antibodies (MAb) specificity for viral surface epitopes demonstrated by immunogold labeling. The MAb used was 3C8. Scale bar $=100 \mu \mathrm{m}$ 


\section{AVND virus tissue distribution and histopathological changes}

Because MAb 3C8 demonstrated the strongest reactivity to AVND virus, it was used for immunofluorescence to detect the virus antigens in diseased scallops during mass mortality. In all cases $(\mathrm{n}=30)$, virus-positive cells (fluorescent cells) were primarily observed in external (protective) epithelia and in the mucosal epithelia of the digestive tract (intestine, stomach). In certain cases, a few positive cells were also present in the connective tissue of some organs, e.g. mantle and gonad (data not shown). On transverse sections of whole mantle, the positive epithelial cells were distributed in a uniform pattern, i.e. dense aggregations of positive cells were only observed to be located in the inner epithelium of the mantle's basal portion as well as in the basal portion of the gills (Fig. 3).
Cellular lesions associated with the positive cells were observed. The positive epithelial cells appeared swollen and disassociated from each other. A disorder or excessive sloughing phenomenon apparently related to the density of the positive cells was clearly recognized in the inner epithelium of the mantle's basal portion. These histopathological changes were also observed in several organs, e.g. in the kidney and stomach (Fig. 4).

No fluorescence was seen in the sections from healthy scallops (serving as the negative control) and the blank control from which the primary antibody was omitted (data not shown).

\section{DISCUSSION}

Although viruses or virus-like particles have been observed ultrastructurally in many bivalves, direct
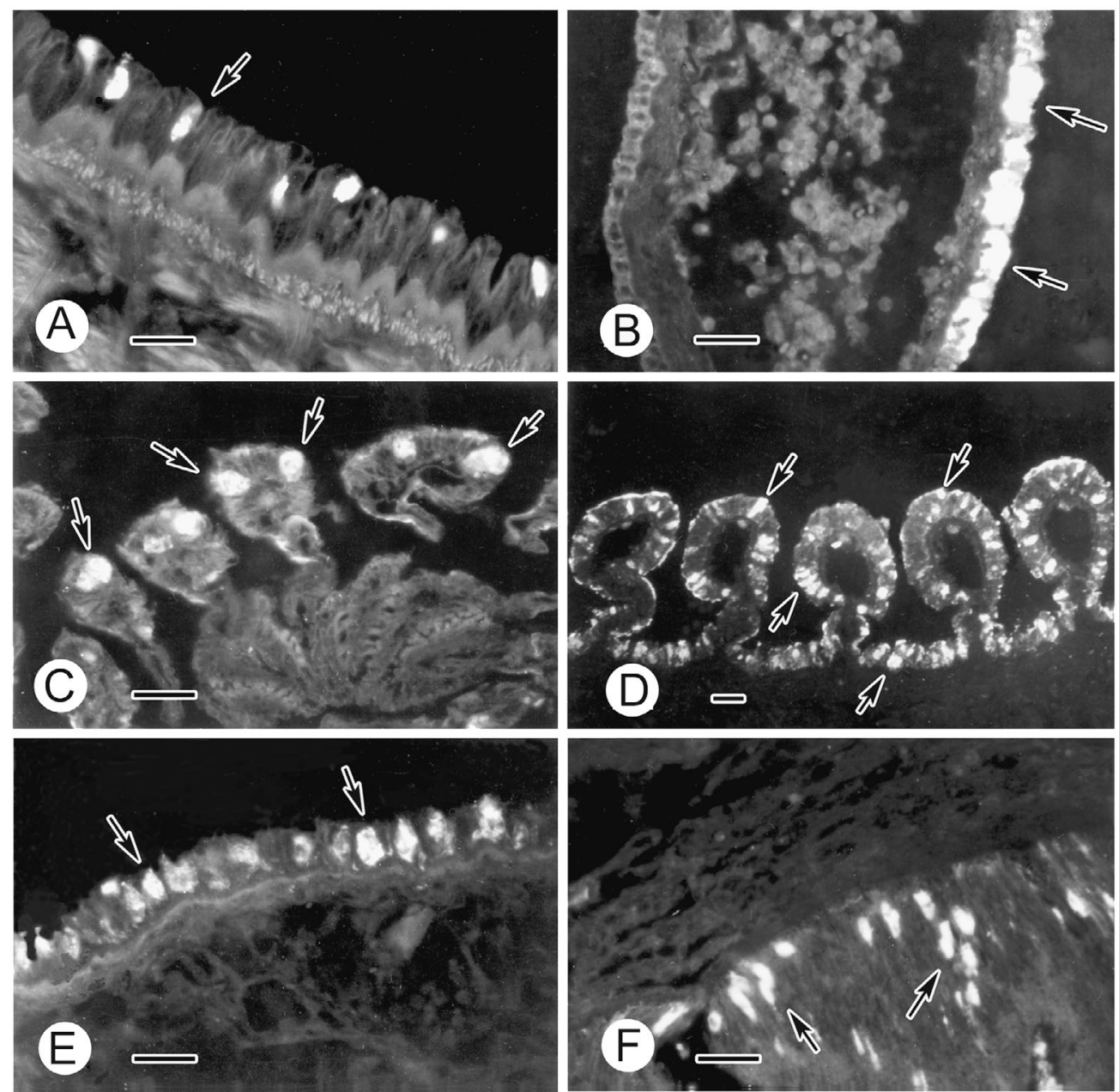

Fig. 3. Tissue distribution of AVND virus in Davidson's solution fixed tissue sections from diseased scallops examined by immunofluorescence assay (IFA) using MAb 3C8. Virus-positive cells (arrows) (A) scattered in mantle's inner epithelium, (B) dense aggregations of cells located in mantle's basal portion, (C) scattered in branchial cells, (D) dense aggregations located in the basal portion of the gills, distributed in (E) external epithelium of the intestine and (F) simultaneously in mucosa of the intestine. 

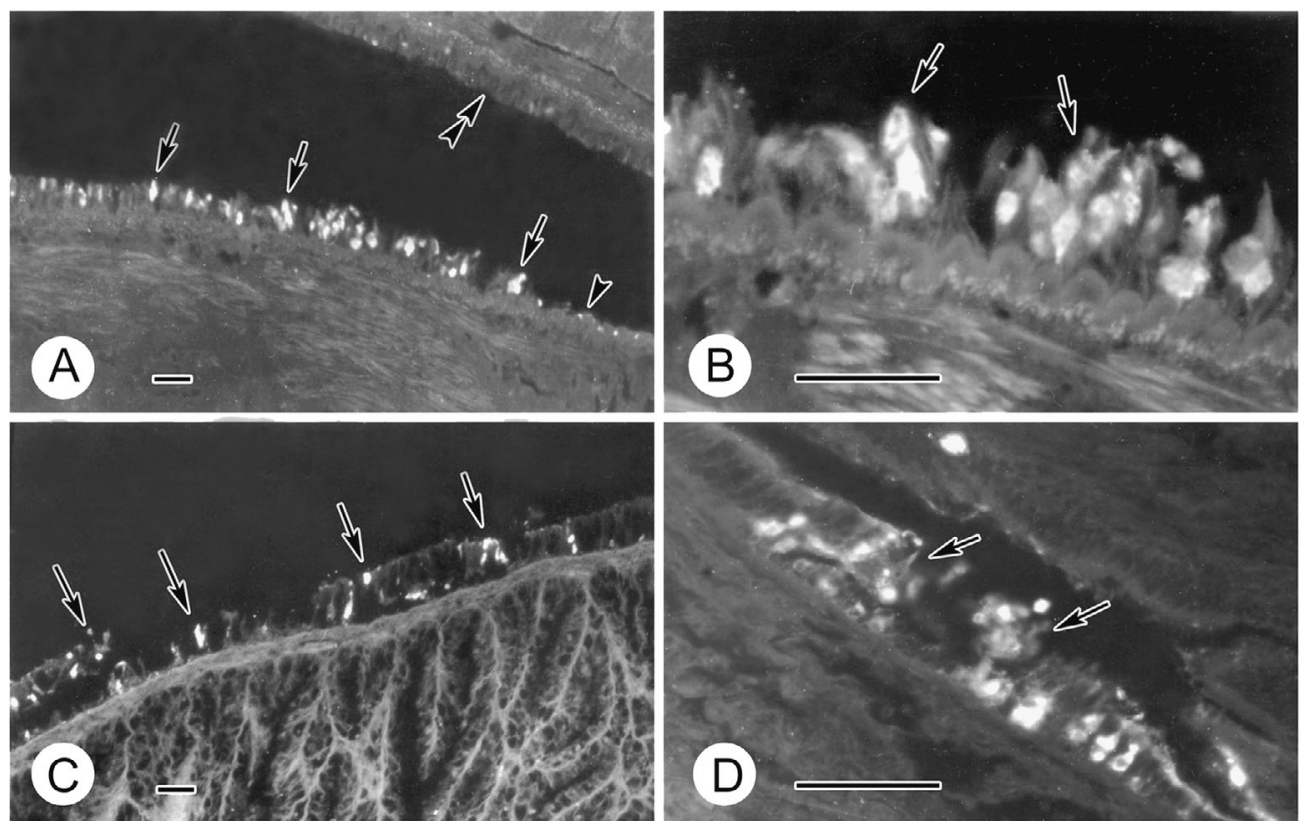

Fig. 4. Histopathological changes coincident with the virus-positive cells detected by IFA using MAb 3C8. (A) Disorder, rupture (arrows), and excessive sloughing (arrowhead) roughly proportional to the intensity of virus-positive cells in the inner epithelium of the mantle's basal portion, compared with the less infected upper portion and uninfected portion (double arrowheads). (B) Magnified central area of (A), showing that the positive cells were swollen and dissociated from each other. Virus-positive cells in (C) outer epithelium of kidney and (D) mucosa of stomach, showing the resultant rupture and sloughing. Scale bars $=25 \mu \mathrm{m}$

evidence linking viral infections with a specific disease is scarce (Elston 1997, Hine et al. 1997). Numerous studies have showed that bivalve molluscs can rapidly accumulate virus from contaminated water (Shieh et al. 1999, Muniain-Mujika et al. 2003). The most significant example may be infectious pancreatic necrosis virus (IPNV), a fish epizootic pathogen that can also be isolated from scallop Pecten maximus but which appeared to be non-pathogenic for adult scallops (Mortensen et al. 1992). In our study, the newly characterized MAbs improved our ability to diagnose infections caused by AVND virus and will make further investigations on the pathogenesis of this scallop etiologic virus possible.

Two screening methods, indirect ELISA and IFA, were used in our study. By ELISA, positive reaction occurred in 12 wells, and by IFA, in 10 wells. This discrepancy may be due to the antigen used in ELISA and the fact that the initial immunization was contaminated with host-derived proteins. This problem was also encountered in some previous studies attempting to develop MAbs to shrimp viral pathogens (Poulos et al. 1999, 2001, Zhan et al. 1999). Although the Western blot assay is a valuable testing format to characterize or confirm the specificity of the MAbs, it is also more time consuming and highly technical. The major drawback to this assay was the requirement that the virus preparation be highly purified. In our study, IEM was performed to further confirm the specificity of selected MAbs and visually detect their specific combining sites on AVND virions. Problems arising from impure virus preparations appear to have been circumvented. This protocol proved to be relatively simple and very rapid. The total time required to test a MAb was about $4 \mathrm{~h}$.

In the present study, a rapid and sensitive IFA testing format was established based on the reliable MAbs and employed to detect the virus tissue distribution in scallop tissues. The results showed that most of the positive cells were located in epithelia of the diseased scallops, though only a few positive cells were simultaneously scattered in connective tissues of some heavily infected individuals. This suggested that AVND virus is epitheliotropic. Some sections were also stained with Harris hematoxylin and eosin (H\&E) with the cytoplasm of the virus-positive epithelia cells appearing more basophilic than uninfected cells (data not shown).

No immunofluorescence was detected in the epithelium of the digestive diverticulae. It is worth pointing out, therefore, that all of the affected epithelial cells were those that in general communicated most directly with seawater. It is possible that when environmental conditions are favorable, the virus may replicate rapidly in infected epithelial cells and then upon rupture of these cells be released and transmitted to other scallops through the seawater. Epithelial disruption 
would allow other opportunistic pathogens colonize the soft tissues, possibly contributing to acute mass mortality among the scallop population.

Acknowledgements. This study was supported by the 'Key Project of Chinese National Programs for Fundamental Research and Development (973 program)' (Project No. G 19990120001). The authors wish to thank Mr. C. M. Wang and J. Y. Huang for their technical assistance in virus purification. We also thank Dr. Z. X. Sun for her technical assistance in cell cultivation.

\section{LITERATURE CITED}

Ai HX, Wang CM, Wang XH, Liu YJ, Li Y, Huang JY, He GJ, Song WB (2003) Atificial infection of cultured scallop Chlamys farreri by pathogen from acute virus necrobiotic disease. J Fish Sci China 10:386-391

Bradford MM (1976) A rapid and sensitive method for the quantitation of microgram quantities of protein utilizing the principle of protein-dye binding. Anal Biochem 72: 248-254

Elston R (1997) Bivalve mollusc viruses. World J Microbiol Biotechnol 13:393-403

Gowen B, Bamford JK, Bamford DH, Fuller SD (2003) The tailless icosahedral membrane virus PRDI localizes the proteins involved in genome packaging and injection at a unique vertex. J Virol 77:7863-7871

Guo X, Ford SE, Zang F (1999) Molluscan aquaculture in China. J Shellfish Res 18:19-31

He GZ, Li Y, Song WB, Wang CM, Huang JY, Wang XH (2003) The relationship between pathogenic infection status and mortality of the scallop Chlamys farreri. J Fish China 27:273-277

Hine PM, Wesney B (1997) Virus-like particles associated with cytopathology in the digestive gland epithelium of scallop Pecten novaezelandiae and toheros Paphies ventriculosum. Dis Aquat Org 29:197-204

Huang JY, Wang CM, Li Y, Wang XH, Song WB, Huang J (2002) Study on RNA of scallop Chlamys farreri virions and extraction methods. J Ocean Univ Qingdao 32:262-266

Li DF, Sun JF, Wu XZ (2002) Purification and feature of virions from Chlamys farreri. Acta Oceanol Sin 21:145-148

Lightner DV (1996) A handbook of shrimp pathology and diagnostic procedures for diseases of cultured penaeid shrimp. World Aquaculture Society, Baton Rouge, LA

Liu ZC, Wu JQ, Jin FJ (1992) The cause and its prevention of

Editorial responsibility: Albert Sparks,

Seattle, Washington, USA mortalities in cultured scallop Chlamys farreri. Mar Sci 16:9-10

Lucht A, Grunnow R, Moller P, Feldmann H, Becker S (2003) Development, characterization and use of monoclonal VP40-antibodies for the detection of Ebola virus. J Virol Methods 111:21-28

Mortensen SH, Bachere E, LeGall G, Mialhe E (1992) Persistence of infectious pancreatic necrosis virus (IPNV) in scallops (Pecten maximus). Dis Aquat Org 12:221-227

Muniain-Mujika I, Calvo M, Lucena F, Girones R (2003) Comparative analysis of viral pathogens and potential indicators in shellfish. Int J Food Microbiol 83:75-85

Poulos BT, Kibler R, Bradley-Dunlop D, Mohney LL, Lightner DV (1999) Production and use of antibodies for the detection of Taura syndrome virus in penaeid shrimp. Dis Aquat Org 37:99-106

Poulos BT, Pantoja, CR, Bradley-Dunlop D, Aguilar J, Light DV (2001) Development and application of monoclonal antibodies for the detection of white spot syndrome virus of penaeid shrimp. Dis Aquat Org 47:13-23

Shieh YSC, Calci KR, Baric RS (1999) A method to detect low levels of enteric virus in contaminated oysters. Appl Environ Microbiol 65:4709-4714

Song WB, Wang CM, Wang XH, Li Y, Li J (2001) New research progress on massive mortality of cultured scallop Chlamys farreri. Mar Sci 25:23-26

Wang YT, Xiang JH (1999) Studies on causation of the mass mortality of Chlamys farreri. Oceanol Limnol Sin 30:770-774

Wang CM, Wang XH, Song XL, Huang J, Song WB (2002) Purification and ultrastructure of a spherical virus in cultured scallop Chlamys farreri. J Fish China 26:180-184

Wang XH, Wang CM, Li J, Wang XH, Zheng GL, Hu XZ, Gong J, Song WB (2002) Epidemiological study on massive death of the cultured scallop Chlamys farreri in the Jiaozhou Bay. J Fish China 26:149-155

Xiao J, Ford SE, Guo XM (2003) Preliminary study on a parasitic ciliate-Trichodina sp. of Chlamys farreri. Mar Sci 27:77-80

Yu RH, Wang RC, Tian CY, Wang ZP (1998) Discussion on the high mortality and its prevention in scallop, Chlamys farreri. Trans Oceanol Limnol 71(3):69-72

Zhan WB, Wang YH, Fryer LJ, Okubo K, Fukuda H, Yu KK, Meng QX (1999) Production of monoclonal antibodies (MAbs) against white spot sydrome virus (WSSV). J Aquat Anim Health 11:17-22

Zhang FS, Yang HS (1999) Analysis of the cause of mass mortality of farming Chlamys farreri in summer in coastal areas of Shandong, China. Mar Sci 23:44-47

Submitted: January 21, 2004; Accepted: February 5, 2005

Proofs received from author(s): May 23, 2005 